\title{
The influence of the fireclay waste on the microstructure and the physico-mechanical properties of autoclaved aerated concrete
}

\author{
Pavlína Šebestová ${ }^{1}$, Vít Černý ${ }^{2}$, Rostislav Drochytka ${ }^{3}$ \\ Faculty of Civil Engineering, Brno University of Technology, Veveři 331/95, 602 00, Czech Republic \\ E-mail: ${ }^{1}$ sebestova.p@fce.vutbr.cz (corresponding author)
}

\begin{abstract}
Autoclaved aerated concrete is a building material with good thermal insulation properties, which it receives through the pore structure. The production of autoclaved aerated concrete consists of two phases. In the first stage, a porous structure is formed by the reaction of calcium hydroxide and aluminum powder to form hydrogen. In the second stage, the lime and siliceous components react under hydrothermal conditions to form crystalline calcium hydrosilicates which form a binder component in the material. In this paper, the degree of crystallization of calcium hydrosilicates is studied depending on the quantity and fineness of the admixture of the fireclay waste. The effect of three different sizes of the specific surface of the fireclay waste on the microstructure and physico-mechanical properties of the autoclaved aerated concrete was monitored. At the same time, the influence of sand substitute for waste was monitored. The amount of the substitute was $10 \%, 30 \%$ and $50 \%$. Finally, the influence of the fireclay waste admixture on the autoclaved aerated concrete porous structure was assessed. The microstructure was analyzed by X-ray diffraction. Based on the achieved values, it can be said that the admixutre of fireclay waste has a positive effect on the crystallisation of calcium hydosilicate phases. Fireclay waste substitution is possible up to $50 \%$. With a higher amount of substitution, the increasing pressure of autoclaved aerated concrete compression is monitored.
\end{abstract}

Keywords: autoclaved aerated concrete, fireclay waste, aluminum powder, calcium hydrosilicate, tobermorite.

\section{Introduction}

The increasingly popular issue of environmental protection and sustainability around the world leads to new material innovations using by-products from various industries. Autoclaved aerated concrete has a high potential for high-level waste utilization due to its ability to bind oxides to the structure of crystalline calcium silicate phases. Many researches point to the possibility of using different types of ashes and other by-products or waste from production (Dilmore \& Neufeld, 2001; Holt \& Raivio, 2005; Huang, Ni, Cui, Wang, \& Zhu, 2012; Ma, Cai, Li, \& Jian, 2016; Song, Li, Yang, Liu, \& Ding, 2015; Wang et al., 2016). The physico-mechanical properties of aerated autoclaved concrete depend primarily on its microstructure, type of binder and filler used, porosity, pore size distribution and matrix curing (Narayanan \& Ramamurthy, 2000).

The creation of thermal insulation properties of autoclaved aerated concrete consists in the chemical reaction of the substances. The aluminum powder reacts under alkaline conditions to form hydrogen gas. This is mixed into the matrix during the liquid or plastic phase of the autoclaved aerated concrete mixture to increase the volume of the mass. Leaving the gas leaves a porous structure in the aerated concrete matrix. There are two types of pores, macropores and micropores in the structure. Macropores result from expansion of mass caused by aeration, and micropores appear in walls between macropores. The pore structure significantly affects the physico-mechanical properties of autoclaved aerated concrete. (Alexanderson, 1979; Narayanan \& Ramamurthy, 2000) After the product matrix has hardened, another process of production technology comes up, namely autoclaving. Autoclaving is carried out at elevated pressure and temperature in saturated water vapor. In this process, new products, the so-called calcium hydrosilicates (hereinafter referred to as $\mathrm{C}-\mathrm{S}-\mathrm{H}$ ) are produced, which impart strength characteristics to autoclaved aerated concrete. The main phase is $11 \AA$ tobermorite, which essentially contributes to the strength characteristics and forms the binder component in aerated concrete (Drochytka, 1993). Many aspects affect the formation of new C-S-H phases. One of them is the characteristics of the raw materials.

The specific surface of the quartz sand influences the morphology and amount of the tobermorite phase (Cai et al., 2016; Isu, Ishida, \& Mitsuda, 1995). As the specific surface area of the siliceous material rises, the reaction surface increases and the required length of the hydrothermal curing process is reduced. However, the dissolution of a high

(C) 2019 Authors. Published by VGTU Press. This is an open-access article distributed under the terms of the Creative Commons Attribution (http://creativecommons.org/licenses/by/4.0/) License, which permits unrestricted use, distribution, and reproduction in any medium, provided the original author and source are credited. 
amount of silicon component can cause the formation of tobermorite to deteriorate and gyrolite from the tobermorite phase penetrates after 64 hours. (Isu et al., 1995) For these reasons, too high a specific surface area of the silica component may reduce the strength characteristics of the starting product (Ma, Cai, Jian, \& Su, 2014).

The main characteristic of siliceous raw materials is their mineralogical character, amorphous or crystalline form of the raw material, when their ability to dissolve into a solution and form Si4+ ions changes. The nature of the siliceous substance most influences the properties of the formed CSH gels. When using silica quartz silica, gels with a $\mathrm{C} / \mathrm{S} \approx 1,69$ molar ratio are produced, i.e. they are calcium rich. These gels are characterized by shorter chains. Conversely, the use of amorphous quartz produces gels with a $\mathrm{C} / \mathrm{S} \approx 0,81$ molar ratio, i.e. they are silicon rich. They have longer chains that make it harder to crystallize (Barnes \& Scheetz, 1989).

As described in the literature, the formation of tobermorite promotes the presence of aluminum ions. $\mathrm{Al} 3+$ ions replace $\mathrm{Si}^{4+}$ ions in tetrahedral chains, as well as $\mathrm{Si}-\mathrm{O}-\mathrm{Si}$ interlayers (Barnes \& Scheetz, 1989; Cai et al., 2016; Huang et al., 2012). When using amorphous $\mathrm{SiO}_{2}$, the substitution of $\mathrm{Si}^{4+}$ ions by $\mathrm{Al}^{3+}$ ions is faster and larger (Siauciunas $\&$ Baltusnikas, 2003). Depending on the strength characteristics, the Al atoms more readily form a bond with the $\mathrm{Si}$ atoms and hence the crystalline tobermorite phase is more easily formed.

The research focused on the possibility of using fireclay waste, which arises in the metallurgical industry. Various specific surfaces of fireclay waste and their influence on microstructure, bulk density and compressive strength of samples were also investigated for complex results. The influence of aluminum powder on physical-mechanical properties and microstructure formation was also investigated to determine the suitability for use in aerated concrete production.

\section{Materials and metods}

The study was conducted in two phases. The first phase evaluates the influence of the specific surface and the amount of secondary raw material on the porous concrete composite without the pore structure (hereinafter composite), without the use of aluminum powder. The second phase evaluates the effect of porous structure formation in aerated concrete (hereinafter AAC) using aluminum powder.

Table 1. Mix-desing of AAC and composite

\begin{tabular}{|l|c|c|}
\hline Raw materials & AAC [\% wt.] & Composite [\% wt.] \\
\hline Cement & 14 & 14 \\
\hline Lime & 8 & 8 \\
\hline Gypsum & 3 & 3 \\
\hline Quartz sand & 73 & 73 \\
\hline Aluminum powder & 0.055 & - \\
\hline Degreasing additive & 0.003 & 0.003 \\
\hline
\end{tabular}

The Table 1 shows the AAC and composite formula. This recipe is substituted by fireclay waste. The water coefficient is the same for all recipes, namely 0.55 .

The basic raw material mixture consists of quicklime, cement, quartz sand, gypsum and aluminum powder. The basic requirement for quicklime is high purity ( $95 \%$ by weight) and a gradual rise in temperature when hydrated. The used Portland cement has the designation CEM I $52.5 \mathrm{~N}$ and guarantees handling strength before autoclaving. The gypsum contains over $90 \%$ calcium sulfate dihydrate, which promotes the formation of thixotropic structure in the fresh mixture and promotes the formation of new crystalline calcium hydrosilicates (CSH). Aluminum powder releases hydrogen gas when reacted with calcium hydroxide, which forms a porous structure of aerated concrete. Quartz sand contains high levels of crystalline silica and only $8 \%$ impurities

Fireclay waste. These are remnants of fireclay blocks (bricks, pipes, etc.) used in the manufacture of sand molds serving as gating systems through which liquid metal is distributed. Fireclay waste contains about $5 \%$ fireclay.

Fireclay waste was adjusted to a specific surface area using a spherical laboratory mill at three finenesses, $160 \mathrm{~m}^{2} / \mathrm{kg}, 253 \mathrm{~m}^{2} / \mathrm{kg}$ and $370 \mathrm{~m}^{2} / \mathrm{kg}$. The figure shows the untreated fireclay waste and the firecly waste after adjusting the specific surface to $253 \mathrm{~m}^{2} / \mathrm{kg}$.

According to chemical analysis (Table 2), the fireclay waste contains over $60 \%$ of the silica necessary for the formation of calcium silicate phases. Further, the feedstock contains a high amount of alumina which, as explained in the introduction, promotes the formation of tobermorite. In this case, however, it may be aluminum oxide in the form of mullite, which occurs in refractory materials. Mullite is unreactive under hydrothermal conditions and thus has no effect on tobermorite formation. For this reason, the scanning electron microscope is performed on the materials. Mullite is visible on the chamotte blocks in Figure 1. 
Table 2. Chemical composition of fireclay waste

\begin{tabular}{|l|c|c|c|c|c|c|}
\hline \multicolumn{7}{|c|}{ Chemical composition } \\
\hline Oxide & $\mathrm{CaO}$ & $\mathrm{MgO}$ & $\mathrm{SO}_{3}$ & $\mathrm{Al}_{2} \mathrm{O}_{3}$ & $\mathrm{SiO}_{2}$ & $\mathrm{Fe}_{2} \mathrm{O}_{3}$ \\
\hline Fireclay waste & 1.18 & 0.334 & 0.14 & 23.2 & 63.8 & 1.66 \\
\hline
\end{tabular}
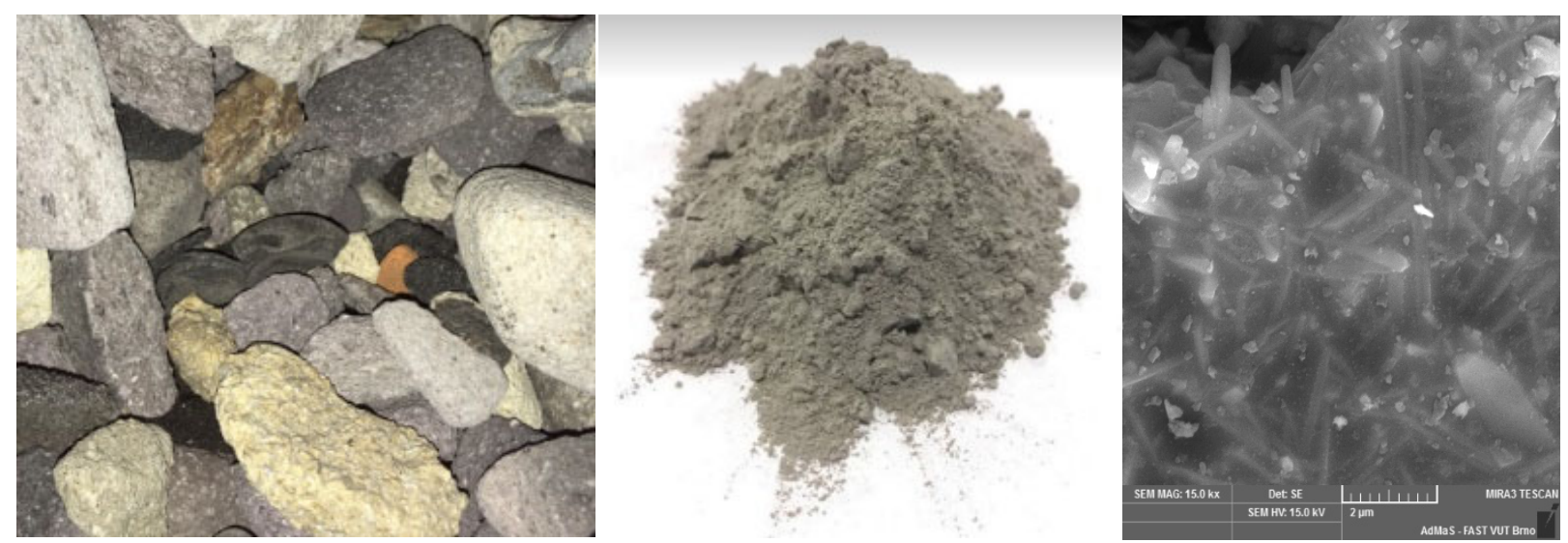

Figure 1. In the left images - unmodified fireclay waste, In the middle images - firecly waste after adjusting the specific surface to $253 \mathrm{~m}^{2} / \mathrm{kg}$, In the right images - SEM image of fireclay waste

\section{Sample preparation}

Samples without the use of aluminum powder (composite) sized $20 \times 20 \times 100 \mathrm{~mm}$. The raw materials were dry homogenized. Subsequently, water was added to the raw materials to create a consistency of the cast dough. The mixture was poured into molds and after 24 hours the samples were removed.

Aluminum powder samples (AAC) of $100 \times 100 \times 100 \mathrm{~mm}$. Lime, cement and fireclay waste were dry homogenized. A slurry was formed from the aluminum powder and degreasing agent. The next step was the production of gypsum-sand suspension at a temperature of $(35 \pm 1)^{\circ} \mathrm{C}$. A dry mixture was added to the gypsum-sand suspension followed by an aluminum suspension. The mixture was poured into molds and after 24 hours the samples were removed.

Samples were autoclaved in a laboratory autoclave under saturated water vapor. The holding time was set at 7 hours and the temperature at $190^{\circ} \mathrm{C}$.

\section{Determination of physical-mechanical properties}

The compressive strength was determined on dried samples at $(105 \pm 5){ }^{\circ} \mathrm{C}$. The test was carried out according to ČSN EN 679 "Determination of compressive strength of autoclaved aerated concrete" (Český normalizační institute, 1995a). The test specimen is inserted into the press in a direction perpendicular to the mass growth and is loaded at a constant rate of $(0.1 \pm 0.05) \mathrm{MPa} / \mathrm{s}$. The specimens tested were $100 \times 100 \times 100 \mathrm{~mm}$. Bulk density was determined after a sample of ČSN EN 678 standard "Determination of dry weight of autoclaved aerated concrete" Český normalizační institute, 1995b).

\section{Sample preparation for microstructure study}

X-ray diffraction. Nuclei were prepared from the samples and ground to a maximum size of $0.1 \mathrm{~mm}$ using a vibrating mill in the first stage of sample preparation for microstructure study. The milled sample was further milled in an isopropanol suspension with the addition of a reference standard in MC Microne mill to a grain size of $<0.02 \mathrm{~mm}$. The resulting suspension was then dried and the resulting powder applied to an Empyrean Panalitical instrument to perform a quantitative XRD analysis.

Scanning electron microscope. For scanning microstructure by scanning electron microscopy, representative fragments of $5 \times 5 \times 5 \mathrm{~mm}$ were selected. The study was performed using a TESCAN MIRA 3 XMU microscope.

\section{Results and discussion}

\section{Influence of fineness of secondary raw material on composite}

Density of the composite peaked at milling waste Fireclay $250 \mathrm{~m}^{2} / \mathrm{kg}$, it applies to all types of substitution. With a higher or lower surface area of the fireclay, a decrease in the bulk density of the composites is seen relative to the 
reference. From these values, it can be assumed that the grinding of firecly at $250 \mathrm{~m}^{2} / \mathrm{kg}$ achieves the highest homogeneity. This phenomenon can probably be explained by the fact that quartz sand achieves the same surface area as fireclay waste with a specific surface $250 \mathrm{~m}^{2} / \mathrm{kg}$. Due to the same fineness of grain fraction are all equally represented, and thus does not produce cement - calcium matrix cavity and macropores.

The compression strength of the reference sample did not reach any of the fireclay waste composites. The compressive strength of the reference composite was most closely matched by composites with $30 \%$ and $50 \%$ fireclay substitutions. In general, higher strengths can be observed with fireclay samples with a specific surface area of $250 \mathrm{~m}^{2} / \mathrm{kg}$. These results indicate that fireclay does not have a significant effect on compressive strength and thus the assumption that most of the aluminum ions are firmly incorporated into the mulite structure has been confirmed. Thus, aluminum ions cannot support the formation of tobermorite in autoclaving (Matsui et al., 2011).

This result was also confirmed by X-ray analysis. In the Figure 2, the measured intensities of the tobermorite peak are shown. A slight increase in intensity can be seen in the sample with $10 \%$ fireclay waste substitution. A $10 \%$ and $30 \%$ substitution can also be observed to see a linear increase in tobermorite peak intensities. With $50 \%$ substitution, this linear increase is no longer observed. Conversely, with the highest fireclay waste substitution, we see a slight increase in the tobermorite peak at the smallest specific surface.

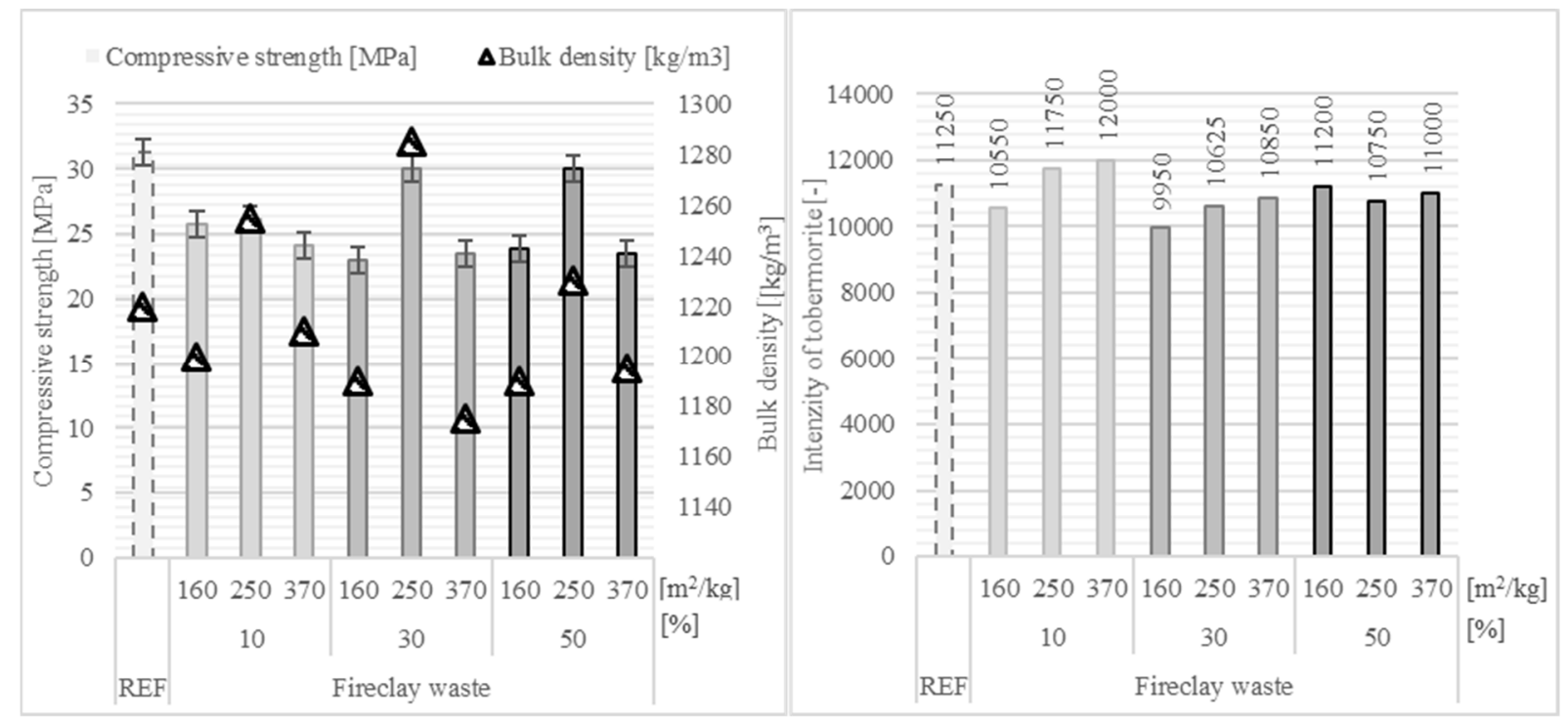

Figure 2. Left graph - dependence of compressive strength on quantity and specific surface fireclay waste, right graph - dependence of tobermorite intensity on quantity and specific surface fireclay waste

\section{Influence of aluminum powder}

The Figure 3 shows the comparison of composite and AAC. AAC achieves about $85 \%$ less compressive strength than composite due to aeration of the mixture. The highest value was achieved by AAC with $50 \%$ fireclay waste. However, the strengths range from (4.3 \pm 5$) \mathrm{MPa}$ around the strength of the reference AAC. It can thus be said that the secondary raw material slightly increases the compressive strength of AAC. In view of the lower amount of fireclay waste silica compared to silica sand and the same specific surface area, it has been suggested to reduce compressive strengths with increasing substitution. The results are likely to be due to the glassy silica phase of the fireclay waste. The glassy silica phase is in an amorphous form, which is easier to dissolve in the hydrothermal reaction to form a more crystalline C-S-H phase (Siauciunas \& Baltusnikas, 2003).

As expected attained AAC lower bulk density than the composite. The decrease in bulk density is less than $50 \%$ compared to the composite without aluminum powder. This value corresponds to the amount of aluminum powder used. The structure is also influenced by the viscosity of the mixture, which in this case was kept constant due to the maintenance of the water coefficient.

The Figure 4 shows a comparison of tobermorite intensities in AAC and composite. It is clear from the diagram that tobacorite AAC intensities have a slight linear increase. This result corresponds to the increase in strength. Thus, it confirms the described mechanism of quicker reaction of amorphous silica. When comparing the tobermorite intensities of AAC and composite, there is a decreasing trend in AAC. Increased crystallization of the tobermorite phases in the formed pores, which give new products a space for recrystallization, was expected. Two assumptions are likely to explain inverting results. Probably calcium hydroxide was bound to the inert compound in the reaction of the aluminum powder (Kanehira, Kanamori, Nagashima, Saek, \& Visbal, 2013). By reducing the non-inert alkaline compounds, the dissolved silicic acid was not used as much as in the composite. This assumption also supports the presence 
of amorphous silica in fireclay waste, which dissolves more readily and uses calcium hydroxide more quickly. (Siauciunas \& Baltusnikas, 2003) Thus, further reactions take place at a reduced $\mathrm{Ca} / \mathrm{Si}$ ratio at which long chains of C-S-H gels are formed, making them difficult to crystallize into tobermorite (Isu et al., 1995).

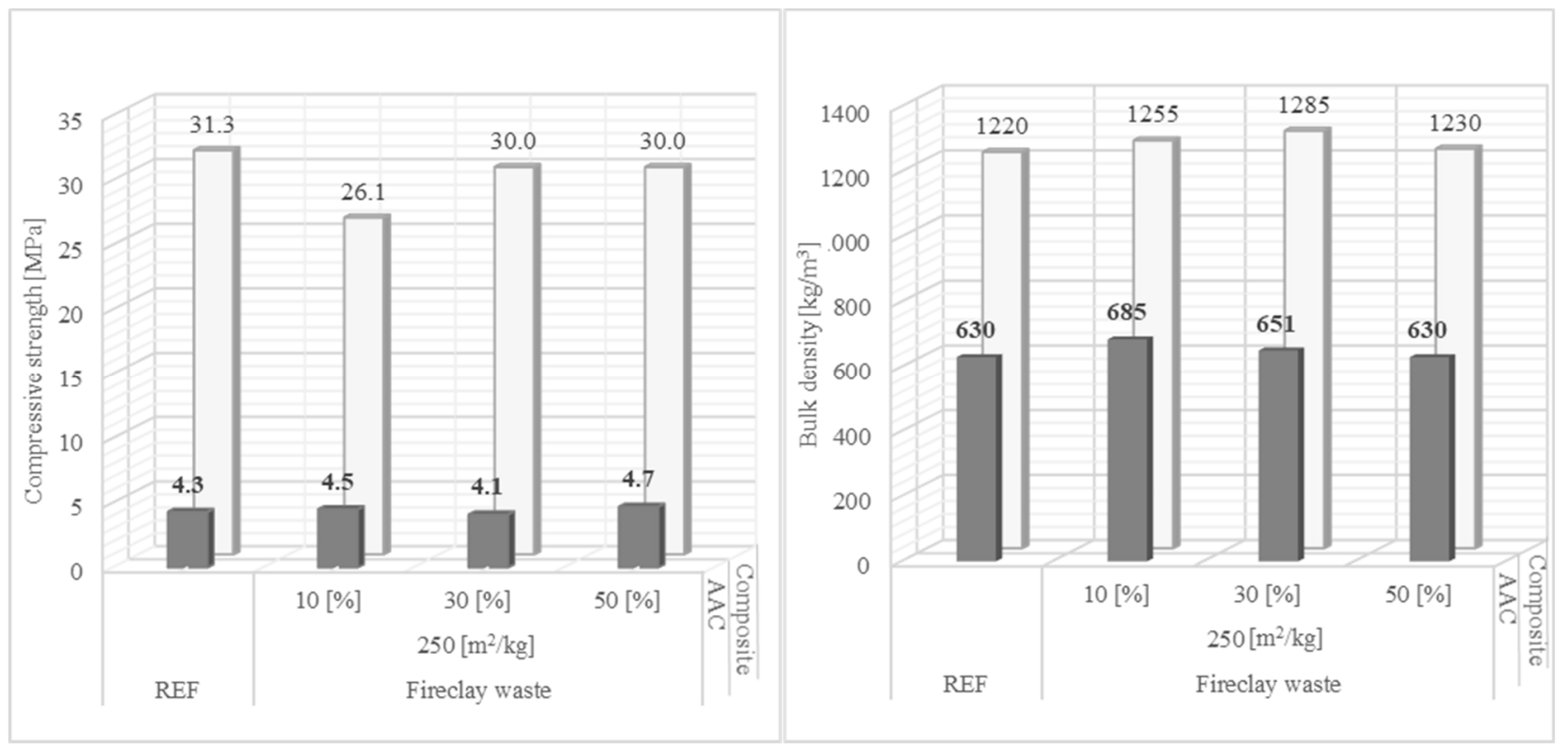

Figure 3. Left graph - compressive strength AAC and composite, Right graph - bulk density of AAC and composite

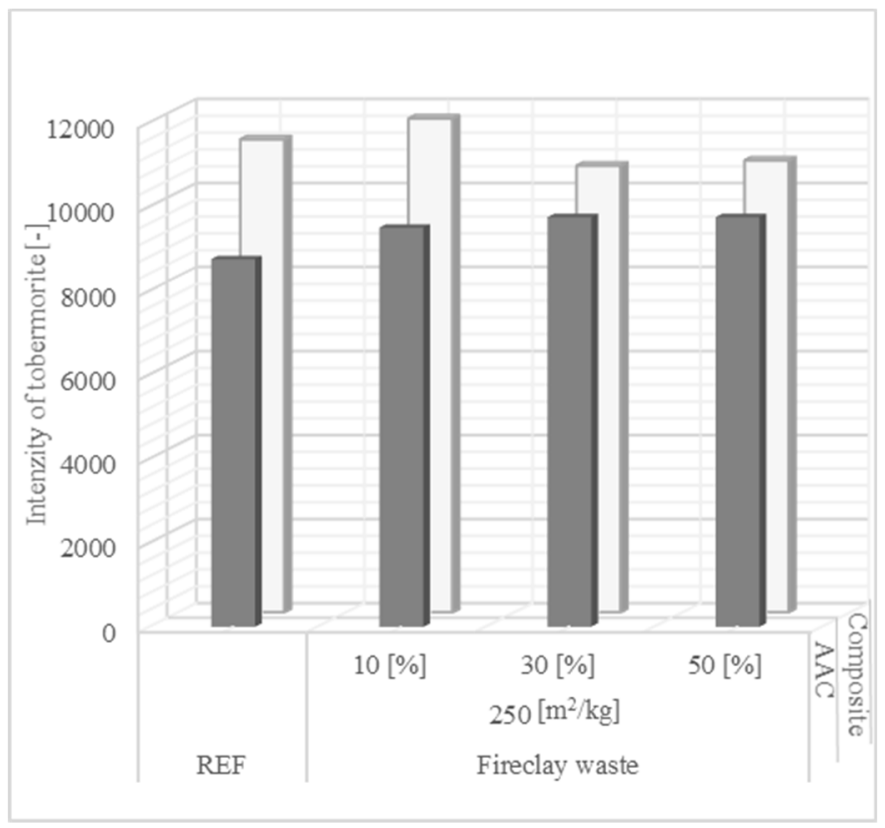

Figure 4. Intenzity of tobermorite of AAC and composite

\section{Conclusions}

Fireclay was adjusted to three specific surfaces of $160 \mathrm{~m}^{2} / \mathrm{kg}, 253 \mathrm{~m}^{2} / \mathrm{kg}$ and $370 \mathrm{~m}^{2} / \mathrm{kg}$, and the effect of fineness on physical-mechanical properties and microstructure was observed. Fireclay with a specific surface area of $250 \mathrm{~m}^{2} / \mathrm{kg}$ achieves the highest strengths of the tested substitutions. With this specific surface, it also achieves the highest homogeneity matrix that predicts the retention or enhancement of strength characteristics.

In the second phase, the effect of aeration of the AAC mixture against the dense composite was studied. AAC achieved an average of $85 \%$ lower compressive strengths and, on the other hand, achieved $50 \%$ lower bulk density than dense aerated concrete.

In both phases the influence of the amount of fireclay waste substitution, which was substituted for silica sand in $10 \%, 30 \% 50 \%$, was studied. The results showed increasing linear dependence of compressive strength on the amount 
of firecly waste. The maximum substitution was $50 \%$. At this ratio, higher compressive strengths and also increased crystallization of tobermorite were observed.

\section{Acknowledgements}

This paper was elaborated within project No. [17-14198S] "Kinetics of silicon microstructure formation in dependence on hydrothermal conditions and type of used materials", and was also funded under [FAST-J-19-6008] "Research into the possibility of maximum utilization of secondary raw materials and aerated concrete in aerated concrete production technology".

\section{References}

Alexanderson, J. (1979). Relations between structure and mechanical properties of autoclaved aerated concrete. Cement and Concrete Research, 9(4), 507-514. https://doi.org/10.1016/0008-8846(79)90049-8

Barnes, S. M. W., \& Scheetz, B. (1989). The chemistry of al-tobermorite and its coexisting phases AT $175^{\circ} \mathrm{C}$. Proceeding Library Archive, 179, 179-243. https://doi.org/10.1557/PROC-179-243

Cai, L., Ma, B., Li, X., Lv, Y., Liu, Z., \& Jian, S. (2016). Mechanical and hydration characteristics of autoclaved aerated concrete (AAC) containing iron-tailings: Effect of content and fineness. Construction and Building Materials, 128, 361-372. https://doi.org/10.1016/j.conbuildmat.2016.10.031

Český normalizační institut. (1995a). Stanovení pevnosti v tlaku autoklávovaného pórobetonu (ČSN EN 679).

Český normalizační institut. (1995b). Stanoveni objemové hmotnosti v suchém stavu autoklávovaného pórobetonu (ČSN EN 678).

Dilmore, R., \& Neufeld, R. D. (2001). Autoclaved aerated concrete produced with low NO x burner/selective catalytic reduction fly ash. Journal of Energy Engineering, 127(2), 37-50. https://doi.org/10.1061/(ASCE)0733-9402(2001)127:2(37)

Drochytka, R. (1993). Lehké stavebni látky. Vysoké učení technické, Brno. 124 s.

Holt, E., \& Raivio, P. (2005). Use of gasification residues in aerated autoclaved concrete. Cement and Concrete Research, 35(4), 796-802. https://doi.org/10.1016/j.cemconres.2004.05.005

Huang, X., Ni, W., Cui, W., Wang, Z., \& Zhu, L. (2012). Preparation of autoclaved aerated concrete using copper tailings and blast furnace slag. Construction and Building Materials, 27(1), 1-5. https://doi.org/10.1016/j.conbuildmat.2011.08.034

Isu, N., Ishida, H., \& Mitsuda, T. (1995). Influence of quartz particle size on the chemical and mechanical properties of autoclaved aerated concrete (I) tobermorite formation. Cement and Concrete Research, 25(2), 243-248. https://doi.org/10.1016/0008-8846(95)00003-8

Kanehira, S., Kanamori, S., Nagashima, K., Saek, T., \& Visbal, H. (2013). Controllable hydrogen relase via aluminium powred corrosion in calcium hydroxide solutions. Journal of Asian Ceramic Societies, (1), 8. https://doi.org/10.1016/j.jacer.2013.08.001

Ma, B., Cai, L., Li, X., \& Jian, S. (2016). Utilization of iron tailings as substitute in autoclaved aerated concrete: physico-mechanical and microstructure of hydration products. Journal of Cleaner Production, 127, 162-171. https://doi.org/10.1016/j.jclepro.2016.03.172

Ma, B., Cai, L. X., Jian, S. W., \& Su, L. (2014). Influence of fly ash fineness on autoclaved energy conservation block's performance and hydration products. Key Engineering Materials, 599, 302-309. https://doi.org/10.4028/www.scientific.net/KEM.599.302

Matsui, K., Kikurama, J., Tsunashima, M., Ishikawa, T., Matsuno, S., Ogawa, A., \& Sato, M. (2011). In situ time-resolved X-ray diffraction of tobermorite formation in autoclaved aerated concrete: Influence of silica source reactivity and $\mathrm{Al}$ addition. Cement and Concrete Research, 41(5), 510-519. https://doi.org/10.1016/j.cemconres.2011.01.022

Narayanan, N., \& Ramamurthy, K. (2000). Structure and properties of aerated concrete: a review. Cement and Concrete Composites, 22(5), 321-329. https://doi.org/10.1016/S0958-9465(00)00016-0

Siauciunas, R., \& Baltusnikas, A. (2003). Influence of $\mathrm{SiO} 2$ modification on hydrogarnets formation during hydrothermal synthesis. Cement and Concrete Research, 33, 1789-1793. https://doi.org/10.1016/S0008-8846(03)00200-X

Song, Y., Li, B., Yang, E., Liu, Y., \& Ding, T. (2015). Feasibility study on utilization of municipal solid waste incineration bottom ash as aerating agent for the production of autoclaved aerated concrete. Cement and Concrete Composites, 56, 51-58. https://doi.org/10.1016/j.cemconcomp.2014.11.006

Wang, C., Wang, N., Zhang, S.-q., Wang, S., Gai, G.-s., \& Wang, W-k. (2016). Preparation and properties of autoclaved aerated concrete using coal gangue and iron ore tailings. Construction and Building Materials, 104(1), 109-115.

https://doi.org/10.1016/j.conbuildmat.2015.12.041 